\title{
The Communication Skills and Mathematical Connections of Prospective Mathematics Teacher:A Case Study on Mathematics Education Students, Yogyakarta State University, Indonesia
}

\author{
Djamilah Bondan Widjajanti ${ }^{*}$ \\ a Yogyakarta State University, Indonesia \\ *Corresponding author:dj_bondan@yahoo.com
}

\section{Article history}

Received :11 December 2012

Received in revised form :

30 August 2013

Accepted : 15 September 2013

\begin{abstract}
The purpose of this research is to identify which aspects of the communication skills and mathematics connections of the prospective mathematics teacher that need to be improved. The subjects of the research were 34 fourth-semester students of Mathematics Education Study Program, State University of Yogyakarta, Indonesia, who took Discrete Mathematics course from February to May 2012. The identifications are done through 6 times by quizzes/tests. The aspect of mathematical communication that had been studied was the ability of students in: (1) writing the statements, reasons, or explanations, and (2) using terms, notations, tables, diagrams, charts, drawings, illustrations, mathematical models, or formulas. While the aspect of mathematical connections that had been examined was the ability of students in: (1) stating the relationship between facts, concepts, or mathematics principles, (2) developing a mathematical model of the daily life problems, and (3) mentioning the concept underlying the solution from the given mathematical problems. Results shows that the students tend to be weak in: (1) writing down the reasons, (2) using charts, pictures, and illustrations, and (3) developing a mathematical model.
\end{abstract}

Keywords: Mathematical communication; mathematical connections; prospective mathematics teacher C 2013 Penerbit UTM Press. All rights reserved.

\subsection{INTRODUCTION}

In general, mathematics teacher in Indonesia face some problems as a result of there are still many students who are over-anxious in facing mathematics tests. These excessive anxieties are caused by the wrong assumption from students about mathematics, i.e. mathematics is a very difficult subject and full of formulas. This wrong assumption is a serious problem faced by the teachers as it can weaken the spirit of student learning, so that students are not quite enthusiastic and confident in learning mathematics. In fact, several experts (Skemp, 1971; McLeod, 1992) said that spirit, motivation, enthusiasm, and confidence in learning mathematics to obtain an optimal learning outcome are important.

However, mathematics teachers play an important role in building the student's belief toward mathematics. The key of student's belief which constructed through their interaction with the teacher lies in what the teachers have given to them so far, and how teachers communicate it (Djamilah, 2010). Mathematical learning experiences that have been established, including the ways teachers communicate and connect it with some facts, concepts, principles, structures, theorems, or a mathematical formulas to the students, will affect the students' belief toward mathematics. Thus, having a good communication skill and adequate mathematical connections, becomes important for a prospective mathematics teacher, as according to the National Council of Teacher of Mathematics (NCTM, 2003).

In order to improve the communication skill and mathematical connection for prospective mathematics teacher, firstly, it needs to be identified which aspect from those two capabilities that need to be improved. For this purposes, this descriptive research was conducted. More specifically, this research aims to identify mathematics student's weaknesses in communication skills and mathematical connections.

\subsection{LITERATURE REVIEW}

\subsection{The Skill of Mathematical Communication}

Communication plays a very important role in mathematics class. It is an essential part of mathematics and mathematics education (NCTM, 2000). In fact, Wichelt (2009) considers that communication is a vital skill in mathematics. While Ontario Ministry of Education states that "Mathematical communication is an essential process for learning mathematics because through communication, students reflect upon, clarify and expand their ideas and understanding of mathematical relationships and mathematical arguments" (Ontario Ministry of Education, 2005)

The importance of mathematical communication in mathematics and mathematics education is reflected by the fact that 
this aspect is included in mathematics activities in the mathematics curricula in many countries. From the papers presented at the APEC TSUKUBA International Conference III, 2007, it can be seen that having the mathematical communication has become one of the goals of mathematics are given at schools, such as schools in Singapore, Malaysia, and Philippine (Har, 2007; Lim \& Chew, 2007; Ulep, 2007). In Japan, mathematical communication is not explicitly in the curriculum, but an important part of the problemsolving activities (Isoda, 2007) and is emphasized in the classrooms (Khaing, Hamaguchi, Ohtani, 2007). While in Indonesia, according to the Regulation of the Minister No.22 of 2006 about the standard of contents, one of the objectives of why mathematics is given in school is so that the students are able to communicate some ideas with symbols, table, diagram or other medias to clarify the situation or problem.

For students, involving in mathematical communication, either with teacher or his friends, either orally or written, either at the same time with the learning process or outside the class, will give many advantages to improve his mathematical understanding. According to the National Council of Teacher of Mathematics (NCTM) "When students are challenged to think and reason about mathematics and to communicate the results of their thinking to others orally or in writing, they learn to be clear and convincing" (NCTM, 2000). In addition, the use of mathematical language helps students gain insights into their own thinking and develop and express their mathematical ideas and strategies, precisely and coherently, to themselves and to others (Walk, Congress, Bansho, 2010).

For mathematics teachers, the skills of mathematical communication is not only important for their self, but it is also important for their students. We can imagine the effect that will happen if the mathematics teacher cannot communicate their mathematical thinking to their students in the learning process in the class. As example: (1) teacher cannot give an explanation for the student's question "why is it so?"; (2) teacher writes some unsorted sequences/not logical of steps to proof or to solve a problem; (3) teachers uses mathematics notation inconsistently; or (4) teacher draws geometric shape that is not quite right. Such thing can be the causes of why students think that mathematics is a very difficult subject.

Given the importance of a mathematics teacher to have an adequate skill of mathematical communication, thus the education program for prospective mathematics teacher should define a standard for this skill. NCATE/NCTM has defined a standard for mathematical communication for Secondary Mathematics Teachers with indicators as: (1) communicate their mathematical thinking coherently and clearly to peers, faculty, and others; (2) Use the language of mathematics to express ideas precisely; (3) Organize mathematical thinking through communication; and (4) Analyze and evaluate the mathematical thinking and strategies of others (NCTM, 2003). While Djamilah (2010) define the indicators for the skill of mathematical communication for the prospective mathematics teacher as students that are able to: (1) write a clear and systematic mathematical statement, reason, or explanation from every mathematics argument used to solve the mathematical problem, (2) use the terms, notations, tables, diagrams, charts, illustration, model or mathematics formula appropriately, (3) check or evaluate other's answers correctly.

Specifically for this research, the skills of mathematical communication observed is limited on the skills of mathematical communication in written. The aspects observed includes the ability of students in: (1) writing statements, reasons or explanation; (2) using some Iterms, notations, tables, diagrams, charts, pictures, illustrations, mathematical models or formulas. These both aspects need to be mastered by prospective mathematics teachers so that they are able to give a fair description about mathematics to their students in the future.

\subsection{The Skill of Mathematical Connection}

Since in the primary school, students have already introduced to many mathematics concepts. On how those students develop these mathematics concepts in their mind, is largely depend on their mathematics students (Skemp, 1971). Each day, those mathematics concepts that are on students' mind would have been more and more as they get more experiences. In order to improve those various mathematics concepts to develop some concepts, ideas or new ideas, students must be able to find the relationship between the concepts, and even to find the relationship between a concept with the concept on other subjects and from their daily life. Such ability is called the skill of mathematical connection.

The skill of mathematical connection is very important for students. When students can connect mathematical ideas, their understanding is deeper and more lasting (NCTM, 2000). Mathematics connection capability allows students to see mathematics as a whole, not the parts separated from each other (NCTM, 2000; Ontario Ministry of Education, 2005). Therefore, mathematics programs should give some experiences for students to develop their ability to connect mathematically. In fact, according to NCTM "Instructional programs from prekindergarten through grade 12 should enable all students to: (1) recognice and use connection among mathematical ideas; (2) understand how mathematical ideas interconnect and built on one another to produce a coherent whole; (3) recognice and apply mathematics in contexts outside of mathematics" (NCTM, 2000). By having adequate skill of mathematical connection, students will be able to see the relation between one formula to another, and be able to see the usefulness of mathematics in other fields and in everyday life.

Mathematics teachers are required to be able to help student to develop their ability of mathematical connection so that students can learn mathematics with fully understanding. According to Mousley "Much advice about teaching for understanding implies that teacher should help children to develop connections between aspects of their experience, knowledge, and skills" (Mousley, 2004). As the ability of mathematical connection is very important, NCATE/NCTM includes mathematical connection as one of the standard process that a mathematics teacher must have. This standard process is that "Candidate recognizes, use, and make connections between and among mathematical ideas and in context outside mathematics to build mathematical understanding" (NCTM, 2003).

As the ability of mathematical connection is important for students and mathematics teachers, prospective mathematics teachers need to be provided with an adequate ability of mathematical connections. To be able to recognize and use the relationships between concepts or mathematics ideas is important for prospective mathematics teachers so that they are able to teach mathematics as a whole, rather than concepts that are not interconnected. If students find that a single formula can be obtained from other formulas, such as the formula of trapezoid area can be derived from the formula of rectangular area, then the students become aware that not all formulas should be memorized. The more relationships that students know, the more they realized that mathematics is not a subject with full formulas that need to be memorized. To be able to recognize and apply mathematics in the context outside mathematics, either within a lesson, or in everyday life, is also important for prospective mathematics students so that they will be able to demonstrate to their students in the future that mathematics has many advantages. According to Ontario Ministry of Education "making connections between the mathematics they study and its applications in their everyday lives helps students see 
the usefulness and relevance of mathematics beyond the classroom" (Ontario Ministry of Education, 2005).

Specifically for this study, the ability of mathematical connections observed is limited to the ability of written mathematical connections. Aspects observed includes the ability of students in: (1) stating the relationship between facts, concepts, or mathematics principles, (2) developing a mathematical model from the daily problems, and (3) mentioning some concepts underlying the solution of the given mathematics.

\subsection{METHODOLOGY}

The type of this research is descriptive. The purpose of the research is to identify which aspects of the communication skills and mathematical connections of the prospective mathematics teachers that need to be improved. The subjects of the research were 34 fourth-semester students of Mathematics Education Study Program, State University of Yogyakarta, Indonesia, who took Discrete Mathematics course from February to May 2012.

The instruments used to collect the data were in form of Mathematics Discrete questions/problems. There were 6 questions about communication, 6 questions about connections, and 2 questions about communication and connection, that are given to the students through 6 times quizzes/tests over a period of February - May 2012. One example of mathematical communication problems that are given to the students is as follows:

Misalkan $S=\{0,1,2,3,4,5,6,7,8,9,10,11,12,13,14,15\} . A$ adalah sembarang himpunan bagian dari $S$ yang mempunyai 9 elemen. Tanpa mendaftar semua elemen yang mungkin dari A, yakinkah anda bahwa pasti terdapat 2 elemen dari A yang jumlahnya 15? Mengapa?

(Let $S=\{0,1,2,3,4,5,6,7,8,9,10,11,12,13,14,15\} . A$ is any subset of $S$ which has 9 elements. Without listing all the possible elements of $A$, are you sure that there are two elements of $A$ that the sum is 15 ? Why?)

While one example of a mathematical connection problems given to students is as follows:

Adakah hubungan antara menentukan banyaknya kombinasi dengan menentukan banyaknya permutasi? Jelaskan seperti apakah hubungan tersebut.

(Is there a connection between determining the number of combinations with determining the number of permutations? Explain what kind of connection)

To identify the aspects of weaknesses of students, the researcher prepared the assessment rubric for the communication and mathematical connections. For the mathematical communication skills, there were two aspects that were assessed, namely: (1) Clarity of writing the statement, reason, or explanation, and (2) The accuracy of the use of the terms, notation, tables, diagrams, charts, drawings, illustrations, mathematical models, or formulas. While for the ability of mathematical connections there are three aspects that were assessed, namely: (1) Correctness of statement of connection between facts, concepts, or principles of mathematics, (2) Correctness of mathematical model developed, and (3) Correctness of the mention of the concept underlying the solution of given mathematical problems. Score each aspect is 0,1 , 2 , or 3 .

From the data collected, it will describe: (1) category of the communication skills and the ability of mathematical connection of students who were the subjects of this research, (2) the aspects in which students tend to be weak, (3) examples of mistakes made by students. Guidelines for the categorization of communication skills and mathematical connections ability are in Table 1 as follows.

Table 1 Capabilities categorization

\begin{tabular}{cc}
\hline Total Score Achieved $(\mathrm{X})$ & Category \\
\hline $\mathrm{X}>\bar{X} i+1.8 \mathrm{Si}$ & Very High \\
$\bar{X} i+0.6 S i<\mathrm{X} \leq \bar{X} i+1.8 S i$ & High \\
$\bar{X} i-0.6 S i<\mathrm{X} \leq \bar{X} i+0.6 S i$ & Medium \\
$\bar{X} i-1.8 S i<\mathrm{X} \leq \bar{X} i-0.6 S i$ & Low \\
$\mathrm{X} \leq \bar{X} i-1.8 \mathrm{Si}$ & Very Low \\
\hline
\end{tabular}

$$
\bar{X} i=\frac{1}{2} \text { (the possible maximum score }+ \text { the possible }
$$
minimum score) and $\mathrm{Si}=\frac{1}{6}$ (the possible maximum score - the possible minimum score).

\subsection{RESULTS AND DISCUSSION}

Table 2 below represents the frequency distribution of scores achievement of mathematical communication skills.

Table 2 Frequency distribution of score of mathematical communication skill

\begin{tabular}{ccccccc}
\hline $\begin{array}{c}\text { Question's } \\
\text { Number }\end{array}$ & Aspect & \multicolumn{6}{c}{ Score } & Total \\
\hline 1 & 1 & 2 & 7 & 15 & 10 & 34 \\
& 2 & 1 & 9 & 10 & 14 & 34 \\
2 & 1 & 14 & 12 & 6 & 2 & 34 \\
& 2 & 10 & 7 & 9 & 8 & 34 \\
3 & 1 & 13 & 14 & 5 & 2 & 34 \\
& 2 & 9 & 10 & 9 & 6 & 34 \\
4 & 1 & 6 & 13 & 8 & 8 & 35 \\
& 2 & 4 & 4 & 16 & 10 & 34 \\
6 & 1 & 12 & 10 & 6 & 6 & 34 \\
& 2 & 8 & 12 & 10 & 4 & 34 \\
7 & 2 & 8 & 14 & 9 & 3 & 34 \\
8 & 2 & 7 & 10 & 11 & 6 & 34 \\
\hline
\end{tabular}

From the data in Table 1, it was obtained total score of 34 students in 8 questions is 706 for the maximum possible total score of 1428. These results are included in the category of "medium". Total score for the first aspect, namely the "Clarity of writing the statement, reason, or explanation" is 274 from a possible maximum total score of 612. These results are included in the category of "medium". Whereas for the second aspect, namely "The accuracy of the use of the term, notation, tables, diagrams, charts, drawings, illustrations, mathematical models, or formula" a total score is 432 from a possible total score of 816 , also included in the category of "medium". It can be concluded that the mathematical communication skills of prospective mathematics teacher who were the subjects of this research are included in "medium" category.

However, when observed in more detail on the student answer sheets, some trends can be seen quite apprehensive, especially in reasoning and create illustrations. For example, in answer to 
Question 2, students basically know the strategy that should be used is to use the Pigeon Hole principle. But in reality, most students (over 50\%) not clear in communicating their answers, or incorrect using illustrations. One example of a student answers is seen in Figure 1 as follows.

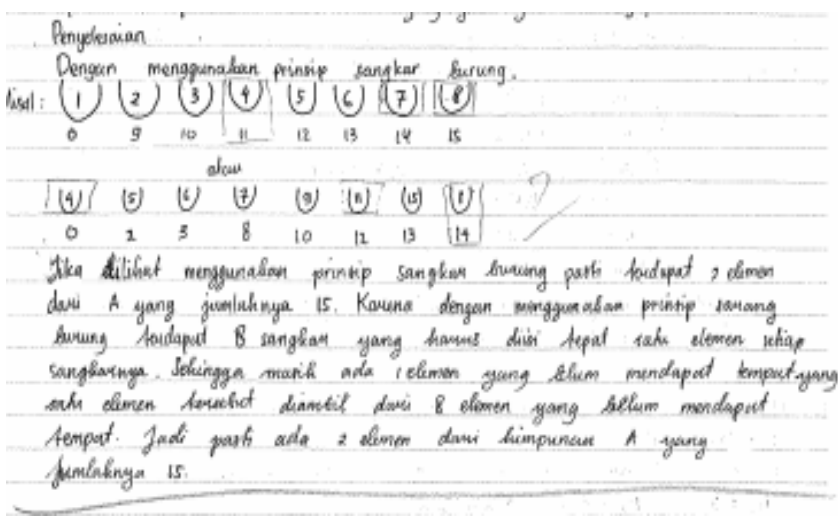

Figure 1 Example of student answer

The student explicitly mentions the use of the principle of Pigeon Hole. But the illustration for the Pigeon Hole is wrong. Also, the explanation is still far from the correct answer. Related to the ability of mathematical connections, Table 3 below shows the results.

Table 3 Frequency Distribution of Score of Mathematical Connections Skill

\begin{tabular}{ccccccc}
\hline $\begin{array}{c}\text { Question } \\
\text { Number }\end{array}$ & Aspect & \multicolumn{6}{c}{ Score } & Total \\
\hline 1 & & $\mathbf{0}$ & $\mathbf{1}$ & $\mathbf{2}$ & $\mathbf{3}$ & \\
2 & 1 & 0 & 8 & 10 & 16 & 34 \\
3 & 2 & 2 & 5 & 13 & 14 & 34 \\
4 & 2 & 3 & 12 & 7 & 7 & 34 \\
5 & 2 & 12 & 12 & 14 & 12 & 34 \\
6 & 2 & 14 & 12 & 5 & 2 & 34 \\
7 & 3 & 1 & 5 & 14 & 14 & 34 \\
8 & 3 & 2 & 6 & 15 & 11 & 34 \\
\hline
\end{tabular}

From the data in Table 3, obtained the total score is 394 of possible maximum total score of 816 . This result is included in the category of "medium". When seen the results for each aspect, the category of those are not the same. Total score for the first aspect, namely "Correctness of statement of connection between facts, concepts, or principles of mathematics" is 126 of a possible maximum total score of 204. This result is included in the category of "high". Whereas for the second aspect, namely "Correctness of mathematical model developed", total score is 147 of a possible total score of 408. These results were categorized as "low". The third aspect, namely "Correctness of the mention of the concept underlying the solution of given mathematical problems", total score is 115 from a possible total score of 204. This result is included in the category of "medium". It can be concluded that the mathematical connections skill of prospective mathematics teachers who were the subjects of the research is classified as "medium", although for the ability to develop a mathematical model is still relatively "low".

Consider to those results, it seems the ability of prospective mathematics teachers to develop mathematical models still needs more attention. Moreover, to develop a mathematical model in the form of recurrence relations as well as on questions that tested. For example, a problem of mathematical connection number (6) as follows.

Suatu string desimal merupakan katakode yang valid dalam suatu sistem komputer jika string tersebut memuat sejumlah genap digit o. Contoh. 1230550821 valid dan 120028790 tidak valid. Misalkan $a_{n}$ menyatakan banyaknya katakode valid dengan panjang $n$. Tentukan relasi rekurensi untuk $a_{n}$

(A decimal string is a valid code word in a computer system if the string contains an even number of digits 0 . For examples 120028790 is valid, whereas 1230550821 is invalid. Let's $a_{n}$ represents the number of valid code words of length $n$, determine the recurrence relation for $a_{n}$.)

Apparently there are more of $75 \%$ of students are "wrong" or "inappropriate" in compiling the required recurrence relation. One example of the student answers is seen Figure 2 follows.

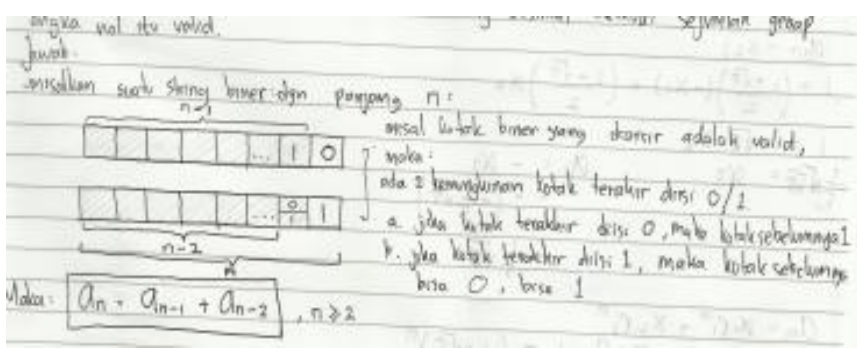

Figure 2 Example of student answer in compiling recurrence relation

From the answer it appears that the student is still struggling to see the problem as a whole. The answer obtained is still "far" from the correct answer. The correct answer is $\mathrm{a}_{\mathrm{n}}=8 \mathrm{a}_{\mathrm{n}-1}+10^{\mathrm{n}-1}, \mathrm{n}$ $\geq 2$.

Regarding to that results, it becomes important for education program of prospective mathematics teacher to explicitly include communication standards and mathematical connections in their learning process, as contained in the NCATE / NCTM Program Standards (NCTM, 2003) and recommendations of CUPM (Dossey, Halvorsen, and McCrone , 2008). Mundy and Findell (2004) also suggest the importance of mathematics teachers have the ability in making connections and explaining among mathematical ideas. Seems to have more and more mathematics curriculum in many countries that explicitly emphasizes the importance of communication skills and mathematical connections as one of the important processes in learning and doing mathematics (Chapman, 2012)

\subsection{CONCLUSIONS AND RECOMMENDATIONS}

This research shows: (1) communication and mathematical connections skills of prospective mathematics teacher who were the subject of this research are classified as "medium", (2) the students tend to be weak in writing the reasons, using charts, pictures, and illustrations, and developing a mathematical model; and (3) ability to develop mathematical models, particularly in the form of recurrence relations, classified as "low".

Based on these results, the recommended solution for improving communication skills and mathematical connections of prospective mathematics teachers is the use of collaborative problem-based learning strategy. Essentially, this strategy relies on the use of challenging problems to guide the lectures and to emphasize the collaboration between students in solving some 
problems given by the lecturer. With such strategy, students have some opportunities to practice more often using some charts, pictures, and illustrations, and to develop a mathematical model from a given problem. The research of Djamilah (2010) shows the superiority of collaborative problem-based learning strategy compared to conventional strategies, particularly in promoting problem solving and mathematical communication skills of prospective mathematics teacher.

\section{References}

Chapman, O. 2012. Challenges in Mathematics Teacher Education. J Math Teacher Education. 15: 263-270. DOI 10.1007/s10857-012-9223-2.

Djamilah Bondan Widjajanti. 2010. Analisis Implementasi Strategi Perkuliahan Kolaboratif Berbasis Masalah dalam Mengembangkan Kemampuan Pemecahan Masalah Matematis, Kemampuan Komunikasi Matematis, dan Keyakinan terhadap Pembelajaran Matematika. Disertasion. Bandung: Universitas Pendidikan Matematika.

Dossey, J., K. Halvorsen, and S. McCrone. 2008. Mathematics Education in the United States. Online http://www.nctm.org/about/affiliates/content.aspx?id=16955

Har,Y. B. 2007. The Singapore Mathematics Curriculum and Mathematical Communication. Paper presented at APEC-TSUKUBA International Conference III, December 9-14, 2007, Tokyo Kanazawa and Kyoto, Japan.

Isoda, M. 2007. How can we develop classroom communication? With an example of classroom dialectic. Paper presented at APEC-TSUKUBA International Conference III, December 9-14, 2007, Tokyo Kanazawa and Kyoto, Japan.

Khaing, T. T, K. Hamaguchi, and M. Ohtani, M. 2007. Development Mathematical Communication in the Classroom. Paper presented at APECTSUKUBA International Conference III, December 9-14, 2007, Tokyo Kanazawa and Kyoto, Japan.
Lim, C. H., and C. M. Chew. 2007. Mathematical Communication in Malaysian Bilingual Classroom. Paper presented at APEC-TSUKUBA International Conference III, December 9-14, 2007, Tokyo Kanazawa and Kyoto, Japan.

McLeod, D. B. 1992. Research on Affect in Mathematics Education: A Reconceptualization. In Grouws, D. A (eds.) Handbook of Research on Mathematics Teaching and Learning. New York: Macmilian Publising Company.

Mousley, J. 2004. An Aspect of Mathematical Understanding: The Notion of "Connected Knowing". Proceedings of the 28th Conference of the International Group for the Psychology of Mathematics Education. 3: $377-$ 384

Mundy, J. F., and B. Findell. 2004. The Mathematical Education of Prospective Teachers of Secondary School Mathematics: Old Assumptions, New Challenges. Online

in http://jwilson.coe.uga.edu/EMAT8990/FIRST/papers2004/findell2004.pdf

National Council of Teachers of Mathematics. 2000. Principles and Standards for School Mathematics. Reston: NCTM.

National Council of Teachers of Mathematics. 2003. NCTM Program Standards. Programs for Initial Preparation of Mathematics Teachers. Standards for Secondary Mathematics Teachers. http://www.nctm.org/uploadedFiles/Math_Standards/.

Ontario Ministry of Education. 2005. The Ontario Curriculum. Online in http://www.edu.gov.on.ca/eng/curriculum/elementary/math18curr.pdf

Skemp, R. R. 1971. The Psychology of Learning Mathematics. England: Penguins Book.

Ulep, S. A. 2007. Developing Mathematical Communication in Philippine Classrooms. Paper presented at APEC-TSUKUBA International Conference III, December 9-14, 2007, Tokyo Kanazawa and Kyoto, Japan.

Walk, G., M. Congress, and Bansho . 2010. Communication in the Mathematics Classroom. Online in http://www.edu.gov.on.ca /eng/literacynumeracy/inspire/research/.

Wichelt, L. 2009. Communication: A Vital Skill of Mathematics. Online in http://digitalcommons.unl.edu/mathmidactionresearch/18. 